Özgün Araştırma Research Article

\section{The Role of Allergen Sensitivity on Pityriasis Alba}

\section{Alerjen Duyarlılığının Pitiriazis Alba Üzerindeki Rolü}

\section{ABSTRACT}

Objective: Pityriasis alba is mostly seen in individuals with a history of atopy, although it may occur in non-atopic individuals. Despite many hypothesis, no certain etiologic factor for pitryriasis alba has been determined. We aimed to investigate the roles of environmental factors, inhalant and food allergy sensitization in its etiopathogenesis. Methods: We noted patients' and controls' age, gender, education level of parents, xerosis, hand soap type, bathing frequency, bath water temperature, wind condition in the location, using sun screen cream, sun exposure time, results of inhalant allergen and food allergen testing. Inhalant allergy test was carried out through a skin prick test for children older than two years, and a food allergy test was carried out through prick to prick test for children of all ages.

Results: The findings showed that there were significant relationships between pityriasis alba and xerosis, inhalant allergen sensitization ( $p<0.0001, p=0.009$, respectively).

Conclusion: We conclude that xerosis and inhalant allergen sensitization are associated with pityriasis alba. Therefore, we think that clinicians should suggest moisturizers to patients with pityriasis alba and make their inhalant allergy tests in clinical follow-up of patients.

Keywords: Pityriasis alba, inhalant allergen sensitization, xerosis

\section{öz}

Amaç: Pitiriazis alba atopik olmayan bireylerde görülebilmesine rağmen çoğunlukla atopi öyküsü olan kişilerde görülmektedir. Birçok hipoteze rağmen pitiriazis albanın kesin etyolojisi tanımlanmamıştır. Çalışmamızda çevresel faktörlerin, inhalan ve besin alerjisi sensitizasyonunun pitiriazis alba üzerindeki rollerini araştırmayı amaçladık.

Yöntem: Hastaların ve kontrollerin yaş, cinsiyet, ebeveyn eğitim düzeyi, kserozis durumu, el sabunu tipi, banyo sıklığı, banyo suyu sıcaklığı, ikamet edilen yerin rüzgar durumu, güneş kremi kullanımı, güneş maruziyet süresi, inhalan ve besin alerjisi test sonuçları not edildi. Inhalan alerji testi 2 yaş üzeri çocuklar için deri prick test aracıllğıyla, besin alerji testi tüm yaş gruplarına prick to prick test aracılığıyla yapıldı.

Bulgular: Sonuçlar, pitiriazis alba ile kserozis ve inhalan alerjen duyarlılı̆ı arasında anlamlı ilişkiler olduğunu göstermektedir (sırasıyla $p<0,0001, p=0,009$ ).

Sonuç: Kserozis ve inhalan alerjen duyarlılığının pitiriazis alba ile ilişkili olduğu sonucuna varıyoruz. Bu nedenle, klinisyenlerin pitiriazis alba tanılı hastalara nemlendirici önermeleri ve klinik izlemlerinde hastaların inhalan alerji duyarlılıklarına yönelik testlerini yapmaları gerektiğini düşünüyoruz.

Anahtar kelimeler: Pitiriazis alba, inhalan alerjen duyarlılığı, kserozis
Received/Geliş: 04.03.2021 Accepted/Kabul: 04.06.2021 Published Online: 18.08 .2021

Emine Ece Özdoğru Izmir Tepecik Eğitim ve Araştırma Hastanesi, Çocuk Immunoloji ve Alerji Bilim Dalı, izmir - Türkiye

dreceozdogru3535@gmail.com ORCID: 0000-0001-7792-5771

M. Gönülal 0000-0003-4496-7769 İzmir Tepecik Eğitim ve Araştırma Hastanesi, Deri ve Zührevi Hastalıklar Anabilim Dalı, Izmir, Türkiye

Cite as: Özdoğru EE, Gönülal M. The role of allergen sensitivity on pityriasis alba. Tepecik Eğit. ve Araşt. Hast. Dergisi. 2021;31(2):261-5. (c) Telif hakkı T.C. Sağık Bakanlığı İzmir Tepecik Eğit. ve Araşt. Hastanesi. Logos Tıp Yayıncllk tarafindan yayınlanmaktadır. Bu dergide yayınlanan bütün makaleler Creative Commons Attf-GayriTicari 4.0 Uluslararası Lisansı ile lisanslanmıştr. (c) Copyright Association of Publication of the T.C. Ministry of Health İmir Tepecik Education and Research Hospital.

This journal published by Logos Medical Publishing.
Licenced by Creative Commons Attribution-NonCommercial 4.0 International (CC BY) 


\section{INTRODUCTION}

Pityriasis alba (PA) is a benign skin disease characterized by hypopigmented round or oval-shaped macules and patches ${ }^{(1,2)}$. It most commonly occurs in children aged three to 16 years; however, $90 \%$ of these cases are encountered in children younger than 12. The macules and patches are often located on the face, arms and upper trunk. PA is most common in patients with personal and/or family history of atopy, but it may also occur in non-atopic individuals ${ }^{(3)}$. Even though there are several hypothesis, no certain etiologic factor has been determined ${ }^{(1,3,4)}$. It isn't contagious, and no infectious etiology has been found ${ }^{(1,4)}$. Because of this uncertainty about the PA etiology, we aimed to investigate the roles of environmental factors, inhalant and food allergy sensitization in its etiopathogenesis.

\section{MATERIAL and METHOD}

This prospective study was approved by the Ethical Review Committee of Izmir Tepecik Training and Research Hospital. Patients younger than 18 who presented to the dermatology or pediatric allergy outpatient clinics of the same hospital with facial skin lesions and diagnosed with PA between September 2019 and June 2020 constituted the target population of this study. Patients who had personal and/or family history of atopy, atopic dermatitis, an internal disease, intestinal parasites and common skin rash were excluded. An age-compatible control group consisted of patients who presented to the dermatology outpatient clinic during the study period due to small, infectious skin or nail lesions, with no diagnosis or history of PA, atopic dermatitis, personal and/or family history of atopy, intestinal parasites, internal diseases and common skin rash.

Parameters including age, gender, education level of parents (illiterate, elementary school, middle school, high school, university, masters, doctorate), living area (windy/not windy), xerosis (absent/present), bathing frequency (every day, every other day, twice a week, once a week), bath water temperature (hot/marrow), type of hand soap (liquid/solid), using sun screen cream (yes/no), sun exposure (1-2 hours per day/3-4 hours per day/5-6 hours per day) and inhalant and food allergen testing results were all recorded. The inhalant allergy test was performed as a skin prick test for children older than two years (ALK-Abello, Prick-test diagnostic, Madrid, Spain), and the food allergy test was performed as a prick-to-prick test for all children.

\section{Statistical analysis}

Statistical analysis was performed by Statistical Package for Social Sciences (SPSS Version 17.0, Chicago, IL, USA) software. In the descriptive analysis, data were given as frequencies, percentages, means, and standard deviations. Pearson's chisquare, Spearman and one-way analysis of variance (ANOVA) tests were used for comparing categorical data between groups. The $p$ value was considered significant when it was less than 0.05 .

\section{RESULTS}

The study group included 48 patients; 27 (56.25\%) were male, while 21 (43.75\%) were female. On the other hand, there were 45 patients in the control group. In this group, there were 20 (44.4\%) males and 25 (55.6\%) females. The age range of the study and control groups were [1-16] and [1-15]. Groups were similar regarding mean patient age. In both groups, most of the parents were graduates of elementary school or high school. Xerosis was in 42 of all cases and in 7 of all controls and there was significant relationship between patients and controls $(p<0.0001)$. Thirty-nine cases and 38 controls were using liquid soap, and two groups were similar in this regard $(p=0.68)$. Six cases and five controls were taking a bath with hot water. Forty-one cases and 33 controls took a bath every day or two, while 7 cases and 12 controls were taking a bath once or twice a week. The two groups were not different concerning bath water temperature and bathing frequency $(p=0.76, p=0.15$, respectively). Also, sunscreen use and sun exposure did not impact the risk of PA $(p=0.11, p=0.27, p=0.52$, respectively). Our analysis revealed that 15 study group patients had only inha- 
Table 1. Information about allergic tendency properties of cases and controls.

\begin{tabular}{|c|c|c|c|}
\hline Parameters & Case & Control & $\mathbf{P}$ \\
\hline Age & $7.29 \pm 3.67$ & $6.22 \pm 3.6$ & 0.16 \\
\hline Gender (male/female) (\%/\%) & $27 / 21(56.25 / 43.75)$ & $20 / 25(44.4 / 55.6)$ & 0.26 \\
\hline Education Level (n) (father/mother) & $48 / 48$ & $45 / 45$ & \\
\hline illiterate & $0 / 1$ & $1 / 1$ & - \\
\hline literate & $0 / 4$ & $1 / 2$ & - \\
\hline elementary & $16 / 15$ & $14 / 13$ & - \\
\hline middle school & $2 / 7$ & $4 / 6$ & - \\
\hline high school & $25 / 16$ & $19 / 21$ & - \\
\hline university (BA, BSc or equivalent) & $2 / 4$ & $4 / 2$ & - \\
\hline masters & $2 / 1$ & $1 / 0$ & - \\
\hline Doctorate (PhD or MD) & $1 / 0$ & $1 / 0$ & - \\
\hline Xerosis (n) (yes/no) & $42 / 6$ & $7 / 38$ & $<0.0001^{*}$ \\
\hline Soap type (n) (liquid/solid) & $39 / 9$ & $38 / 7$ & 0.68 \\
\hline Bath water temperature $(n)$ (hot/marrow) & $6 / 42$ & $5 / 40$ & 0.76 \\
\hline \multicolumn{4}{|l|}{ Bathing frequency $(n)$} \\
\hline every day + every other day & 41 & 33 & 0.15 \\
\hline twice a week + once a week & 7 & 12 & 0.15 \\
\hline Living area (windy / not windy) & $26 / 22$ & $17 / 28$ & 0.11 \\
\hline Using sunscreen cream (yes/no) & $5 / 43$ & $2 / 43$ & 0.27 \\
\hline \multicolumn{4}{|l|}{ Sun exposure (hour a day) (n) } \\
\hline $1-2$ hours & 31 & 32 & \\
\hline 3-4 hours & 12 & 7 & 0.52 \\
\hline $5-6$ hours & 5 & 6 & \\
\hline Inhalant allergen (positive/negative) (n) & $16 / 32$ & $5 / 40$ & $0.009 *$ \\
\hline Food allergen (positive/negative) (n) & $3 / 45$ & $1 / 44$ & 0.34 \\
\hline
\end{tabular}

Table 2. Results of inhalant and food allergy testing of patients.

\begin{tabular}{lc}
\hline Allergy tests & Cases (n/\%) \\
\hline *Inhalant allergy & \\
Grass pollens & $8 / 16.3$ \\
D. farinae & $8 / 16.3$ \\
Olea europeae & $7 / 14.3$ \\
Dog hair & $5 / 10.2$ \\
Chenopodium & $3 / 6.1$ \\
Cat hair & $3 / 6.1$ \\
Alternaria & $2 / 4.1$ \\
Parietaria & $2 / 4.1$ \\
Plantago & $2 / 4.1$ \\
Cladosporium & $1 / 2$ \\
Aspergillus fumigatus & $1 / 2$ \\
Cockroach & $1 / 2$ \\
*Food allergy & \\
Egg yolk & $1 / 2$ \\
Egg white & $2 / 4.1$ \\
Walnut & $1 / 2$ \\
Hazelnut & $1 / 2$ \\
Pistachio nut & $1 / 2$ \\
Peanut & $2 / 4.1$ \\
Wheat & $1 / 2$ \\
\hline
\end{tabular}

*Nine patients had sensitivity to two and more inhalant allergens, one patient had sensitivity to seven food allergens.

lant allergen sensitization, 2 study group patients only food and 1 patient had both inhalant and food allergen sensitization. Thirty of the 48 PA patients had no sensitization to inhalant or food allergens. Among the 45 control group patients, 5 had inhalant and 1 had food allergy sensitization. There was signi- ficant relationship between cases and controls about inhalant allergen sensitization ( $p=0.009)$. Thirty-nine of these patients had no sensitization to inhalant or food allergens. Nine patients and one control had sensitivity to two and more inhalant allergens, one patient had sensitivity to seven food allergens. All other data are shown in Table 1 and 2 (Table 1,2).

\section{DISCUSSION}

Our study aimed to investigate the potential role of environmental factors, inhalant and food allergen sensitizations in the etiopathogenesis of PA since the underlying mechanisms are not yet fully understood ${ }^{(4)}$.

Our analysis revealed that xerosis had a significant association with PA. This finding may imply that xerosis can be involved in the pathogenesis of PA. In line with this, Weber et al. reported that xerosis was significantly associated with PA ${ }^{(5)}$. Not surprisingly, individuals with dry skin have low threshold for diseases associated with transepidermal water loss. There are several studies describing xerodermic aspects in patients with PA ${ }^{(6,7)}$. The results of these studies are in line with ours. 
PA is a skin disorder which typically manifests at late summer ${ }^{(5)}$. Recent studies have found direct correlations between PA and sun exposure, lack of sunscreen use and frequency of bathing ${ }^{(8)}$. In our study, we did not find a significant relationship between PA and these parameters as well as water temperature. Weber et al. ${ }^{(5)}$ reported that sun exposure was involved in the pathogenesis of PA, probably as a consequence of the direct action of the ultraviolet radiation on melanocytes. The direct radiation causes a reduction in the number of melanocytes and their activities ${ }^{(9)}$. This process leads to hypomelanosis. It was observed that regular use of filters with higher protection factors (especially $\geq 15$ ) was associated with a lower risk for the development on PA ${ }^{(10)}$. Also, Weber et al. ${ }^{(5)}$ reported that bathing frequency had a more significant association with PA than bath water temperature. This result was not consistent with ours findings. In addition, in the same study, it was found that windy location was effective in forming PA but according to our results we think that windy location isn't effective. Balcı et al. ${ }^{(11)}$ determined that the frequency and duration of bathing, bathwater temperature, and sunscreen use did not influence the risk of PA. However, sun exposure of over 1 hour per day was a significant risk factor for $P A$, according to these researchers $(p=0.007)$.

Balcı et al. ${ }^{(11)}$ did not find a significant relationship between the soap type and the risk of PA. Our findings were in line with this research. We also found that living area did not impact the risk of PA. To our knowledge, the relationship between living area and risk of PA has not been analyzed in the previously published literature.

Our findings showed that there was a significant relationship between PA and inhalant allergen sensitization. The fact that PA lesions are mostly located on the face and the main entry site of inhalant allergens are nose and mouth support this finding. However, we did not find a significant association between PA and food allergen sensitization. Therefore, we suggest that clinicians should consider performing inhalant allergen tests during management of patients with PA.
Although our findings may somewhat explain the facial PA lesions, the mechanisms involved in the formation of the lesions located at other body sites can not be elucidated. Additional studies are needed in this regard.

The allergens represent a significant component of air quality and may have a detrimental impact on health, particularly on respiratory allergic diseases (12). It was reported that the prevalence of inhalant allergen sensitization was in the range of $25-50 \%$, especially in developed countries ${ }^{(13)}$. The most important inhalant allergens consist of pollens (trees, grasses, and weeds), house dust mites, molds and animal danders ${ }^{(14)}$. It was reported that, among the known allergens, house dust mites were the most common ones followed by fungi, pollens and animal epithelia (15). In our study, we determined sensitization to grass pollens, D. farinae, Olea europaea, dog hair, Chenopodium and cat hair in descending order.

To the best of our knowledge, our study is the first to investigate the relationship between PA and environmental factor, inhalant and food allergen sensitization. However, as a limitation, our sample size remained small due to the impact of coronavirus disease 19 pandemia on our healthcare system during the study period.

We conclude that xerosis and inhalant allergen sensitization are associated with PA. Therefore, we think that clinicians should suggest moisturizers to patients with PA and make their inhalant allergy tests in clinical follow-up of patients.

Ethics Committee Approval: SBU Izmir Tepecik Health Practice and Research Center Non-Interventional Ethics Committee approval was obtained (2019/13-5). Conflict of Interest: No conflict of interest was declared by the authors.

Funding: The authors declared that this study received no financial support.

Informed Consent: Consent form was filled out by all participants. 


\section{REFERENCES}

1. Toychiev A, Mirzoeva M, Davis N, Islamova J, Osipova S. Pityriasis alba: possible associations with intestinal helminths and pathogenic protozoa. Int J Clin Pract. 2020;74:e13441.

2. Yamamah GA, Emam HM, Abdelhamid MF, etal. Epidemiologic study of dermatologic disorders among children in South Sinai, Egypt. Int J Dermatol. 2012;51:1180-5.

3. Blessmann Weber M, Sponchiado de Avila LG, Albaneze R, Magalhaes de Oliveira OL, Sudhaus BD, Cestari TF. Pityriasis alba: a study of pathogenic factors. J Eur Acad Dermatol Venereol. 2002;16:463-8.

4. Miazek N, Michalek I, Pawlowska-Kisiel M, Olszewska M, Rudnicka L. Pityriasis alba--common disease, enigmatic entity: up-to-date review of the literature. Pediatr Dermatol. 2015;32:786-91. [CrossRef]

5. Weber MB, Sponchiado de Avila LG, Albaneze R, Magalhães de Oliveira OL, Sudhaus BD, Cestari TF. Pityriasis alba: a study of pathogenic factors. J Eur Acad Dermatol Venereol. 2002;16:463-8. [CrossRef]

6. Uehara M, Miyauchi $\mathrm{H}$. The morphologic characteristics of dry skin in atopic dermatitis. Arch Dermatol. 1984;20:118690.

7. Linde YW. Dry skin in atopic dermatitis. Acta Derm Venereol (Stockh). 1992;177(Suppl.):9-13.

8. Lin RL, Janniger CK. Pityriasis alba. Cutis. 2005;76:21-4.
9. Zaynoun ST, Aftimos BG, Tenekjian KK et al. Extensive pityriasis alba: a histological, histochemical and ultrastructural study. Br J Dermatol. 1983;8:83-90. [CrossRef]

10. Tronier M, Rudolph $P$, Köser T et al. One single erythemogenic UV irradiation is more effective in increasing the proliferative activity of melanocytes in melanocytic naevi compared with fractionally applied high doses. $\mathrm{Br} J$ Dermatol. 1997;137:534-9. [CrossRef]

11. Balcı DD, Sangün Ö, Duran N, Peker E. Pitriyazis albada etiyopatojenik faktörler ve klinik bulgular. Turkiye Klinikleri J Dermatol. 2009;19(1):5-8.

12. Bousquet PJ, Chinn S, Janson C, Kogevinas M, Burney $P$, Jarvis D. European community respiratory health survey I: geographical variation in the prevalence of positive skin tests to environmental aeroallergens in the european community. respiratory health survey I. Allergy. 2007;62:301-9.

13. Mbatchou Ngahane BH, Noah D, Nganda Motto M, Mapoure Njankouo Y, Njock LR. Sensitization to common aeroallergens in a population of young adults in a sub-Saharan Africa setting: a cross-sectional study. Allergy Asthma Clin Immunol. 2016;12:1. [CrossRef]

14. Shoormasti RS, Fazlollahi MR, Kazemnejad A, Tayebi B, Nadali F, Shoushtari MS. IgE Sensitization to Inhalant Allergens and Its Association with Allergic Diseases in Adults. Iran J Allergy Asthma Immunol. 2018;17:123-33.

15. Camacho IGC. Inhalant Allergens in Portugal. Int Arch Allergy Immunol. 2017;172:67-88. [CrossRef] 